\title{
Incidence of a hypermedia educational material on the Teaching and Learning of Mathematics
}

\author{
Laura Sombra del Río ${ }^{1 *}$ (i) , Cecilia Verónica Sanz ${ }^{2}$ (i), Néstor Daniel Búcari ${ }^{3}$ (i) \\ ${ }^{1}$ IMAPEC, Departamento de Ciencias Básicas, Facultad de Ingeniería, Universidad Nacional de La Plata, \\ Argentina \{laura.delrio@ing.unlp.edu.ar\} \\ 2III LIDI, Facultad de Informática, Universidad Nacional de La Plata, CIC, Argentina \\ \{csanz@lidi.info.unlp.edu.ar\} \\ ${ }^{3}$ Departamento de Ciencias Básicas, Facultad de Ingeniería, Universidad Nacional de La Plata, Argentina \\ \{nbucari@ing.unlp.edu.ar\}
}

Received on 6 July 2018; revised on 14 September 2018; accepted on 16 October 2018; published on 15 January 2019

DOI: 10.7821/naer.2019.1.334

(c) BY-NC-ND

\begin{abstract}
The use of hypermedia educational materials in education has gained relevance in recent years and is the object of numerous research activities. In the context of teaching and learning Mathematics, there are diverse works detailing their potential to improve both student learning and student attitude towards the subject. In this article, the results obtained through a case study carried out in a first-year course of Mathematics at a School of Engineering are shared, for which a hypermedia material was designed and then its impact in the classroom was analysed. To that end, a quanti-qualitative analysis framework was designed. An experience was carried out with two groups of students: one of these $(n=101)$ used this material, and the other $(n=111)$ served as control group. The students gave a positive overall assessment as regards to the experience carried out with the hypermedia material, but not to the extent expected. However, observations and the interviews carried out with the educators revealed that the hypermedia material positively contributed to several student learning aspects: it allowed using a mathematical software application as an exploratory tool and it promoted critical thinking among the students, who used the application to check their pen-and-paper work, using the semiotic representation conversions.
\end{abstract}

KEYWORDS: MULTIMEDIA INSTRUCTION, EDUCATIONAL SOFTWARE, EDUCATIONAL TECHNOLOGY, TEACHING MATERIALS, MATHEMATICS.

\section{INTRODUCTION}

The so-called Information and Communication Technologies (ICTs) offer a great diversity of new resources to enrich teaching and learning processes. For instance, the possibility of introducing hypermedia educational materials (HEM), which allow for combining multimedia and hypertext languages, typical of the most widely employed communication channels used nowadays. The advantages and obstacles related to the integration with this type of materials in various educational contexts are being studied

*To whom correspondence should be addressed:

Departamento de Ciencias Básicas, Universidad Nacional de La Plata Calle 115 y 49, 1er piso, La Plata (1900), Buenos Aires, Argentina by several research groups (Argos \& Ezquerra, 2013; Ariza \& Andrada, 2008; Mohamad, Hussin, \& Shahizan, 2015; Rabhe, 2018; Müller \& Seufert, 2018). In particular, for teaching and learning Mathematics, which is a discipline with distinct epistemic characteristics, there are several articles that describe HEM integration design experiences, usually with encouraging results (Di Domenicantonio, Costa, \& Vacchino, 2011; Insunza, Alonso, \& Alvarez, 2009; Pantoja, López, Ortega, \& Hernández, 2014).

This article starts by discussing the results of a bibliography review carried out to study the relevant background related to ICT integration to teaching Mathematics (Section 2). In Section 3 , the theoretical framework for the didactic proposal on which the experience developed is based, is presented. In Section 4, the characteristics of the educational context where the experience was carried out are described, and in Section 5, the description of the HEM that was implemented is presented. Section 6 describes the research methodology used. In Section 7, the results obtained are described and discussed, and in Section 8 the conclusions and future lines of work that open up after the research work carried out are presented.

\section{BIBLIOGRAPHY REVIEW}

The research work presented in this article started with a background bibliography review process in relation to the use of hypermedia educational materials in particular, and ICTs in general, in the area of Mathematics. A systematic search for academic papers on this topic was carried out and presented in el Río, Búcari \& Sanz (2016) Kitchenham et al. (2009) was followed: questions were defined to guide the search process, inclusion and exclusion criteria were established, and sources were selected based on quality criteria. Thirty-four articles, published between 2009 and 2017, were considered for the analysis. Then, an update of this review was made in 2018, including new articles of this year. The following questions were used to guide the analysis and classifying the articles:

A) What are the uses proposed for the materials developed? What hypermedia resources are used? What are the goals for using them?

B) What are the achievement indicators defined by the researchers to analyse if goals were achieved? What are the most relevant research methodologies in the research area? 
C) What are the theoretical frameworks in Mathematics Didactics and/or Educational Technology that support the proposal? Is there dialogue between the disciplines in the context of this research work?

As regards to the first question, most of the articles considered were found to revolve around the design of some application or digital study material aimed at helping with the graphical visualization of concepts and favouring dynamic exploration through the interaction features offered by the digital media (Ascheri, Pizarro, Astudillo, García, \& Culla, 2014; Dolecek, 2012; Gonzalez, Medina, Vilanova, \& Astiz, 2011; Mendezabal \& Tindowen, 2018). Several authors use applets (Aveleyra, Dadamia, \& Racero, 2014; Ramírez Osorio, 2014) and animation (Morales, Herrera, Fennema, \& Goñi, 2014; Pirro et al., 2012) as interactive resource.

Other authors integrate hypermedia technologies to improve some aspect of their lectures, usually out of an interest to facilitate visualization, but without taking advantage of the student-interaction features offered by these materials. For example, in (Schivo, Sgreccia, \& Caligaris, 2009) the authors propose using applets to present theoretical classes as a tool for illustrating the contents being discussed in a dynamic and animated way.

Some of the authors include simulators to approach the issues identified in relation to the teaching and learning process. For instance, to help students propose mathematical models for the operation of a system and observe its behaviour (Aveleyra et al., 2014; Morales et al., 2014; Pirro et al., 2012).

There is a minority of articles where games are used as an element to motivate Mathematics students (Morales et al., 2014; Oliveiro, 2013). In some cases, videos are used, typically to implement the flipped classroom methodology, i.e., theoretical contents are offered in video format and the face-to-face classes are used for different types of tasks, such as problem solving, student consultation, etc. (Coll \& Blasco, 2009; Pantoja et al., 2014; Sun, Xie, \& Anderman, 2018).

Some authors propose the use of hypermedia to demonstrate mathematical procedures step by step. One of such examples is the work presented by Guerra, Mora, Nieves, Pimentel and León (2016), where the authors defend that students, "need tools that can help them understand and visualize the entire process to develop skills to work with matrices" (p. 2). In Barrena, Falcón, Ramírez, \& Ríos (2011), the authors propose using the GeoGebra software application to create presentations showing a step-by-step solution to a problem.

In two of the articles that were reviewed, the use of augmented reality is proposed to improve student comprehension of three-dimensional objects (Martín-Gutiérrez et al., 2010; Yingprayoon, 2015).

Recent works address self-regulated learning in computer-based hypermedia environments, analysing navigation issues, among other indicators (Müller \& Seufert, 2018).

As regards question (B), it was found that the methodologies used by the researchers that are interested in using hypermedia materials to teach Mathematics can be divided into two broad groups based on their driving goal: 1. Improving learning, and 2. Improving student attitude. Some are concerned with both aspects and use methodologies that combine techniques from both groups, while others have well-supported educational proposals but do not put them into practice and, therefore, their group cannot be established.

For the first group, the most commonly used methodology consists of comparing academic performances of groups that used the material designed for any given activity and groups that did not (Guerra et al., 2016; Schivo et al., 2009). To a lesser extent, there are articles where student knowledge on a certain topic is assessed before and after using the material being studied, but no control groups are used. Student production is analysed and interviews are carried out to establish the type of learning that has taken place (Insunza et al., 2009). Also, peers and experts are asked to assess the material for validation purposes (Di Domenicantonio et al., 2011).

As for the second group, aiming at achieving attitudinal improvements through the use of HEM, the following methodologies were observed: student surveys, which is the one most commonly used, and indicators such as decreased absenteeism and increased class participation.

Finally, in relation to the theoretical contributions made by the authors to support the use of HEM for teaching Mathematics, it was found that some authors resort to Educational Technology theoretical contributions but do not take into account the specific aspects of the mathematical knowledge to be taught (Aveleyra et al., 2014; Sorando, 2012), while others resort to theories framed within the specific didactics of Mathematics (Gonzalez et al., 2011). In some cases, there is an attempt to integrate both disciplines (Ascheri et al., 2014; Pantoja Rangel et al., 2014), but only common aspects are highlighted and tensions between them are disregarded.

\section{BACKGROUND}

One of the main conclusions drawn from the bibliographic review phase is that, to support the practices being proposed, a theoretical framework that is based both on the Specific Didactics of Mathematics as well as on Educational Technology should be considered. Below, the aspects of Specific Didactics that are considered to be the most relevant ones for this research work are discussed followed by a similar analysis in relation to Educational Technology.

\subsection{Specific Didactics: The French School}

The so-called French School of Didactics of Mathematics has formulated theories that allow explaining the teaching and learning processes used in Mathematics. For this work, two of those theories have been considered in particular: the Theory of Didactical Situations (TDS) proposed by Brousseau (1986) and Duval's Theory of Registers of Semiotic Representation (Duval, 1998). TDS falls within Piagetian constructivism (Brousseau, 2007) - it states and considers that student work should, at times, be compared to scientific activity: "A good reproduction of a scientific activity by a student would require the student to act; formulate; test; build models, languages, concepts, theories; interchange those with others; recognize those that match the culture; take those that are useful, etc." (Brousseau, 1986). The theory proposed by Duval states that, unlike study objects in other scientific disciplines, mathematical objects, "are not physically accessible through sensory experiences, either directly or through the use of instruments. The only way to access and work with them is through semiotic representations and signs" (Duval, 2006, p. 157). Duval highlights the importance of having students work with different registers of semiotic representation. This involves the abilities of representing and recognizing a mathematical object in different representation registers, being able to perform transformations between registers, and selecting those registers that are most suitable for any given problem situation: "mathematical activity requires internal coordination, which has to be constructed, among the various representation systems that can be chosen and used" (Duval, 2006, p. 158). 


\subsection{ICTs contributions}

The integration of the so-called ICTs to the teaching and learning processes in the educational context is important for the development of the competencies required in professionals nowadays, and in Engineering students in particular (Claro et al., 2012; Humanante-Ramos, García-Peñalvo, \& Conde-González, 2017). Bresco, Verdú and Flores (2012) highlights the multimedia elements and interaction possibilities: "starting from the existence of a diversity of learning styles, and with the wide range of resources offered by information and communication technologies, interactive digital contents are considered as elements that can offer responses to the different styles" (p. 3). Multiple authors (Berney \& Bétrancourt, 2016; Mayer, 2003) highlight the importance of including multimedia elements in educational materials, especially in the case of novice learners. Berney and Bétrancourt (2016), present a meta-analysis of bibliography on the inclusion of animations in educational materials is presented, with the observation that "studying with animation when learning dynamic phenomena is beneficial compared to static graphic displays" (p. 157).

In addition to these aspects, hypermedia materials offer the possibility of connecting information in various ways, helping create non-linear paths: "Hypermedia offers multiple representations that are hyperlinked, thus allowing the student to control the sequencing of information" (Moos, 2014, p. 129).

In short, the aspects of the HEM that are of interest are their semiotic richness, the possibility of enabling non-linear paths in study materials, interactivity possibilities, and the active attitude students are likely to adopt when faced with these features.

\section{EDUCATIONAL CONTEXT FOR HEM}

The experience was developed within the course of [Mathematics A, School of Engineering of the National University of La Plata.]. Since 2002, the teaching methodology implemented by the team of educators starts by questioning the traditional model. Amphitheatre classrooms were replaced by flat classrooms with large tables that accommodate groups of 8-10 students each, to favour peer exchange during the classes. Thus, students work in groups, using a theoretical-practical guide and assisted by a team of educators. In this context, all students are conceived as subjects that are capable of learning the contents, so educators are constantly searching for suitable media and aids to help them achieve that goal (Búcari, Abate, \& Melgarejo, 2007). On each table there is also a computer with mathematical software that the students can use. Learning how to use this type of software application is very important for engineers-to-be, but given the intense nature of the course and the inherent difficulty of classic computer algebra systems (CAS), integration with these resources is usually scarce. For this reason, a strategy to help these students become acquainted with this type of tool was created by integrating contents and activities in a HEM, aimed at presenting different semiotic representations, introducing the use of GeoGebra applets, and promoting an active role in students (Del Río, Búcari, González, 2014) based on the concepts supported by Brousseau and Duval and the possibilities offered by hypermedia materials.

\section{CHARACTERISTICS OF THE HEM DEVELOPED}

The HEM (Del Río, Búcari, \& Sanz, 2015) was based on the contents of the original theoretical-practical guide (printout material), which included the following topics: vectors (introduction and basic operations), straight lines in space, and planes. It was devel- oped using an authoring tool (Moralejo, Sanz \& Pesado, 2014), called eXeLearning. This is a free and open program to create educative content integrating multimedia resources. A hierarchy was created, with parent nodes corresponding to the introduction of the different topics, and child nodes used to provide in-depth information and to carry out related activities.

This HEM is aimed at keeping some of the essential features of the print-out, which is designed to make students work, solve problems and reflect, but it also integrates and exploits the possibilities offered by hypermedia languages. All topics share the same structure: problem situations are presented to the students to foster classroom discussions around the concepts that they should learn. After these situations are presented, and after the students solve them as a group, relevant definitions, property descriptions, theorems and examples are offered in the material. There are also exercises aimed at helping the students master the techniques learned during their classes. The multimedia resources used in our HEM are presented in Table 1.

Table 1. Resources used in the HEM

\begin{tabular}{ll}
\hline Multimedia resources & \multicolumn{1}{c}{ Objective } \\
\hline $\begin{array}{l}\text { Animations with } \\
\text { GeoGebra }\end{array}$ & $\begin{array}{l}\text { Helping understand the dynamic process } \\
\text { carried out to create constructions } \\
\text { Helping students visualize their first 3D } \\
\text { mathematical objects and work with them } \\
\text { (vectors, straight lines in space and planes) } \\
\text { Improving the use of various registers of } \\
\text { with anaglyph glasses } \\
\text { representation }\end{array}$ \\
$\begin{array}{l}\text { Interactive GeoGebra } \\
\text { applets }\end{array}$ & $\begin{array}{l}\text { Proposing construction activities so that } \\
\text { students can explore, conjecture, generalize }\end{array}$ \\
Activities with feedback & $\begin{array}{l}\text { Helping students master calculation techni- } \\
\text { ques through instant feedback }\end{array}$ \\
\hline
\end{tabular}

\section{METHODS}

The scope of this work is descriptive. Quantitative and qualitative methods are triangulated to take into account all the different aspects that affect a complex scenario such as the educational context (Bravin \& Pievi, 2008). Before the experience in the classroom, a survey was distributed among the students of the course of Mathematics A. Three groups of the course used our HEM (experience groups; grand total of 101 students) and the other three were used for comparison (control groups; grand total of 111 students). A convenience sampling technique (Hernández Sampieri, Fernández Collado, \& Baptista Lucio, 2010) was used, which is a non-probabilistic sampling method, because subjects are not randomly selected. Since we decided to work with students in their usual work context, already formed groups of students and educators were used.

For the qualitative approach, different methodological techniques were used. The aim of the qualitative techniques used was to complement and contrast the results from the surveys.

As regards to qualitative techniques, the experience included participant observation to monitor how students worked with the material. Additionally, the educators in charge of the three groups that used the HEM were interviewed for better insight in relation to the observations recorded during the experience and how the students responded.

Finally, written outputs produced by the students in their exams were analysed to determine whether there were any differences between the students in the groups that used the material and those 
in the control groups in relation to the strategies used to approach the activities proposed. Figure 1 depicts a timeline showing when each technique and instrument was applied in each of the groups.

Figure 1. Chronological representation of the implementation of the various data collection instruments in each of the groups

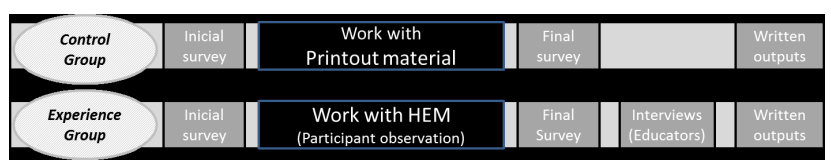

In the following sections, the results obtained with the different data collection instruments used are presented and analyzed, and then they are triangulated to account for the scope and limitations of the teaching experience.

\subsection{The surveys}

The initial survey had three parts. The first part was aimed at characterizing the students to verify if groups were homogeneous in relation to age, gender, nationality, educational background (public/private and orientation chosen in high school), and to take any potential differences into account when analysing the impact of the material in relation to students' attitudes. The second part of the survey was aimed at establishing student access to digital devices and how they use them. The survey presented in (Sanz \& Zangara 2016) was considered when preparing this section of our survey. The third part was oriented to measuring student attitude towards: 1) the use of ICTs as part of the teaching and learning process, 2) Mathematics, and 3) the use of ICTs to learn Mathematics. This measurement has a dual purpose: on the one hand, to further characterize students to establish potential causes for any differences that may be observed in their assessment of the experience and, on the other, analysing if there are any changes in student attitude before and after the experience.

Attitudes were measured using a Likert scale (Hernández et al., 2010). To shape the statements included in the survey to quantify student attitude towards ICTs, the work presented in (Nobile \& Sanz, 2014) was used as reference. To measure student attitude towards Mathematics, the work of Hurtado Mondoñedo (2011) was used as reference. These mentioned instruments considered for building the surveys used in this research, had an appropriated analysis of validity and reliability, as it is stated in the above-cited works.

The final survey (after the experience) had 2 parts. It was applied two weeks after the classroom experience was completed. The first part was the same for all groups (control and experience), and it was identical to the third part of the initial survey. In the second part, students had to indicate if they had found the topics presented during the experience to be easier, harder, or of equal difficulty as those taught in previous classes for the course. The goal behind posing this question for both groups was establishing if there were any differences as regards perceived difficulty between students using the HEM and those who used conventional materials (printouts).

The groups that worked with the hypermedia educational materials also had to assess the various aspects of the HEM. To prepare this part of the questionnaire, the works presented in (Pompeya López, 2008) and (Martorelli, Martorelli \& Sanz, 2014) were used as reference. Some open-ended questions were also included to allow students to provide more detailed information about their experience using the HEM in the classroom - students were asked to mention one positive and one negative aspect of the material.
As already mentioned, a Likert scale was used to analyse students' attitudes. Each student was assigned a value representing his/her attitude. This is an ordinal variable, so Mann-Whitney U test was used to establish the differences between the different groups (Molinero, 2001). The test is applied to samples of two populations $\mathrm{A}$ and $\mathrm{B}$. The null hypothesis is that $\mathrm{A}$ and $\mathrm{B}$ have the same distribution.

To analyse variations in attitudes, a Wilcoxon matched paired test was used, since it compares groups of paired measurements at interval or ordinal measurement levels (Siegel, 1970). In this case, student attitudes measured before (A) and after (B) the experience was considered, both for groups that used the HEM and control groups. In all cases, statistics tests were carried out with Prism 5.0 (https://www.graphpad.com/scientific-software/prism).

Finally, to establish if there was correlation between any of the starting variables (educational background, gender, previous experience using GeoGebra, and so forth) and the final assessment of the HEM, students were split into groups based on the value corresponding to the variable being considered (or within a given range of values) and response distribution was analysed in each of these groups. If any significant differences were observed, it was concluded that the variable did affect student assessment.

\subsection{Participant observation}

This data collection strategy was carried out in the groups that used the HEM while the experience was being developed. General aspects in relation to student attitudes and how these affected classroom dynamics were recorded, as well as conversations between students to establish and describe the strategies they used to approach the activities proposed in the HEM and take control over the applets based on GeoGebra. To do that, an anecdotal record was created with "a specific segment of reality, previously defined and guided by a theoretical framework" (Aragón, 2010, p. 7). To record this information, the observer sat at the tables with the students when they were getting ready to discuss and solve any of the interactive activities proposed in the HEM. The entire discussion is registered, along with student interventions. Sometimes, the observer takes on the role of educator and becomes an active participant (which is also registered). By registering these exchanges, the strategies used by the students in relation to a specific scenario can be described, as well as student interaction with each other and with the HEM.

The results from qualitative analysis allowed the researchers to observe students attitudes towards the HEM, and compare these observations with the results of the survey. In addition to that, they allowed for the description of the strategies students used to learn with the HEM, how they solved the problems proposed involving their previous knowledge, and in comparison with the students of the control groups.

To register the observations during the sessions, notes were taken and then they were reviewed completed immediately after each class, as is recommended by several authors (Aragón, 2010; Bravin \& Pievi, 2008).

\subsection{Interviews with educators}

The semi-structured interview with participating educators was intended as a supplement to student point of view and better understanding the process that took place in the classroom. The educators involved in the experience were interviewed as a group, since "in certain cases, interaction, and in particular group interaction, allows for a more in-depth discussion and favours insight on the phenomena being discussed" (Corbetta \& Fraile Maldonado, 2007, pp. 359-360). 
For this purpose a script has been prepared, including seven questions, as a guide for the interview. Nevertheless, according to the semi-structured format, the interviewer may not follow the script literally to deepen unforeseen aspects that emerge from the conversation (Hernández, Fernández, \& Baptista, 2010).

Questions revolved around students' attitude while working with the HEM (positive or negative, and, if not homogeneous, which type of students they think respond better to the material), how class work affected students habits afterwards (whether students adopted GeoGebra as a learning tool after the experience was over), any differences they may have observed in relation to how the topics included in the HEM are approached as opposed to other groups of students they worked with in previous years, as well as around the material itself (changes they would like to introduce, whether they think the material was a positive contribution as regards attitudinal or cognitive aspects).

Finally, answers given by educators were contrasted with the results of the surveys and the observations of the researchers. Convergent and complementary aspects were analysed. In this way, the results of the different data collection instruments were triangulated (Hernández Sampieri, Fernández Collado, \& Baptista Lucio, 2010).

\subsection{Analysis of student written work at exams}

As regards to student production, the section of exams corresponding to the topic included in the HEM was analysed. The instructions given were analysed and possible solutions were described. Then, student productions were reviewed and classified based on their success, errors made, and tools used.

Categories were defined to group the different solutions presented by the students. Next, the frequency of occurrence of each of these categories in each of the groups being studied was established to determine if there were any significant differences among them.

\section{DISCUSSION AND RESULTS}

\subsection{The surveys}

Even though most of the students rated the experience positively, results were not as clear-cut as expected (52\% positive ratings, $6 \%$ negative ratings, and $40 \%$ indifferent; $2 \%$ of the students did not answer the question). Everyone indicated positive and negative aspects of the HEM. The most frequently mentioned positive aspects were: a) it allowed them visualize 3D objects, b) being able to corroborate their solutions using GeoGebra applets, and c) better insight into the topics being studied (this group of students could not provide details as to why or how the HEM helped them better understand the topic). Figure 2 shows a chart with the frequencies for each of these answers. The most frequently mentioned negative aspects included: a) additional time required to use the HEM, b) difficulties to learn how to use GeoGebra applets, c) lack of enough available computers (which forced them to adapt to the pace of their classmates with whom they shared a computer), and d) the inconvenience of having to carry their portable computers and others borrowed notebooks from the institution. Interestingly, a small group mentioned as a negative aspect that in the exam GeoGebra is not available to them to solve activities. In addition to that they considered using GeoGebra during the classes results in less practice solving activities in the way they are asked to do it for their exams. A similar case was a group of students who stated, that focusing so much on the graphical interpretation results in less practice in relation to the analytical aspects, which is "what really matters".
Figure 2. Positive aspects reviewed by the students and their frequency

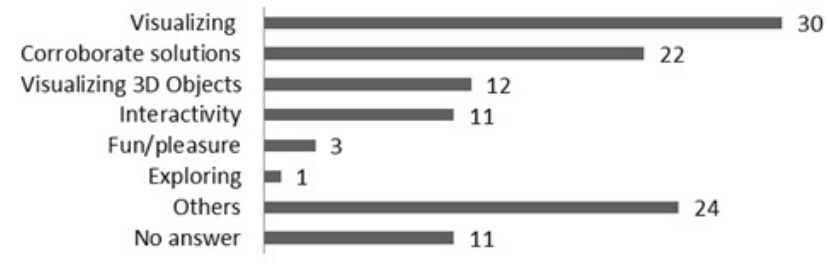

The aspects that the students identified as positive are relevant from a didactic point of view and based on the objectives proposed for HEM integration, since they show improved visualization, better understanding and autonomy when analyzing if a mathematical problem was successfully solved. However, from the point of view of the students, the difficulties they faced had a significant weight, which is evident from the number of students who indicated they were indifferent to the experience. This also seems to have had a negative impact in relation to their attitude, since the groups that used the HEM showed lower ratings for ICTs, both in general as well as when using them as learning tools for Mathematics, after the experience, which did not happen with the control groups (there was also a decrease in their attitude towards Mathematics, but this was also present in the control groups) (Del Río, Sanz \& Bucari, 2017). The following data arising from this analysis are also interesting:

- Both the students who used the HEM and those in the control groups were asked to state if they found the contents learned during the experience to be: a) easier, b) about the same difficulty, or c) more difficult than those learned in the course before the experience. The results for this question are shown in Figure 3. It can be inferred that moving from the plain to the space was slightly less abrupt for the students who worked with the HEM. However, the students probably did not notice this, since they did not go through the more traditional educational path and, therefore, remained unaware of the advantages of the HEM.

- There is another indicator that is considered as a positive response, and this is in relation to the question of whether they would use GeoGebra to work in future new topics. Student answers were 89 Yes, 9 No, and 3 did not answer. The interview with the educators (which was part of the qualitative analysis) is discussed in the following sub-section. It confirms that the software was later on adopted to learn subsequent topics. This was beneficial in the sense of improving the connection between registers of representation.

Figure 3. Students' answers to the question about perceived relative difficulty of the topics taught using HEM and previous topics in the course

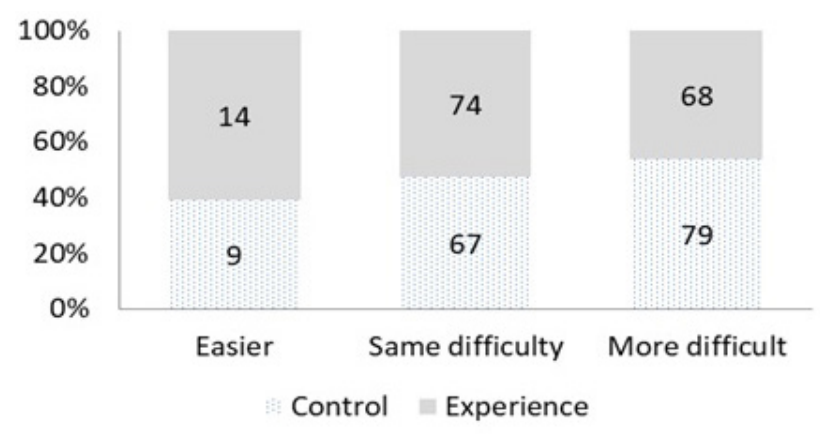


Finally, input variables were matched with the final assessment of the experience so as to establish if there are any future changes that can be implemented to help students better exploit the experience, or to establish which type of student profile finds this material more useful. Multiple correlation analysis were carried out, and only two yielded statistically significant results:

- The students that had already started using GeoGebra in high school gave higher ratings to the experience than those who had never used it (Fig. 4).

- Since the experience was carried out to teach the first topic unit learned after the first exam, their grades were considered as a potential factor that could affect how students rated the experience. It was found that, both for students who failed their exams and for students who obtained high grades, experience ratings were lower than for those who passed with grades lower than or equal to 7 (Fig. 5). This could mean that the students who failed maybe felt discouraged and were not as satisfied with the experience, while those who obtained higher grades in their first exam were less prone to have a positive assessment of the experience because they had already found a successful strategy to pass and the change introduced was more of a hindrance to them.

Figure 4. Experience ratings compared to grades obtained in the first exam

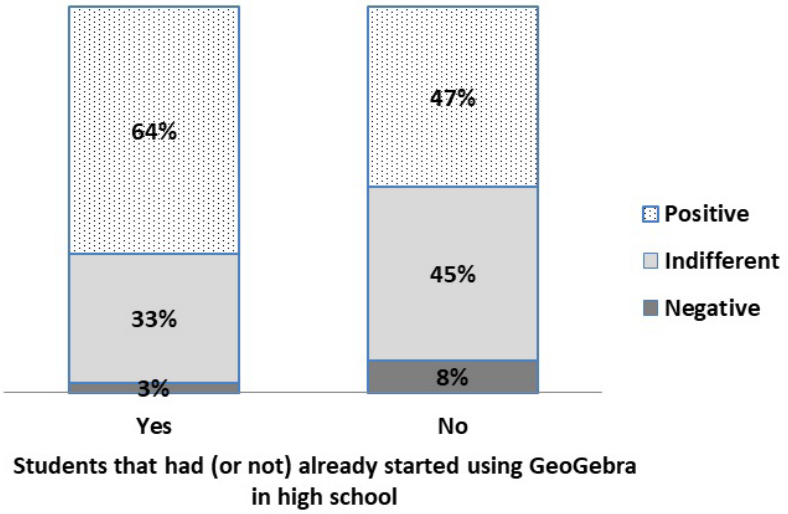

Figure 5. Experience ratings compared to prior use of GeoGebra

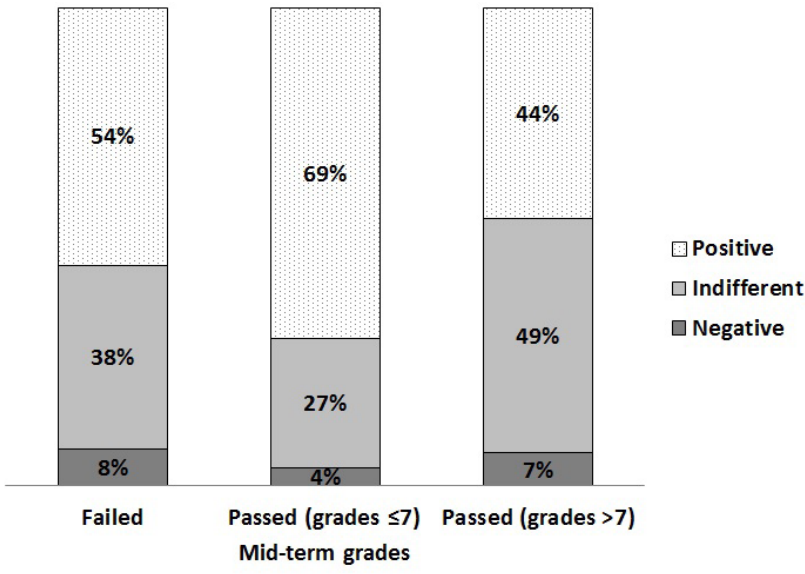

\subsection{About the interviews with the educators}

After the experience ended, the educators from the participating groups were interviewed to add their information to that obtained from students and participant observation. The interviews were recorded and analyzed latter by the researchers. The main results obtained from these interviews are the following:

- As regards the HEM, the educators had a positive opinion about it. The main aspects highlighted by educators were $\mathrm{R}^{3}$ display and using GeoGebra applets.

- Among the challenges they faced, for the most part they mentioned that they had not had enough time to interact with the HEM before the experience to be more familiar with it.

- After the experience, they noted that some students continued using GeoGebra. They brought questions about exercises that they had tried with GeoGebra at home. This is interesting in terms of tool adoption by the students.

- The same as for the students, the educators were concerned with regards to time. They stated that, when a strategy is changed, additional time is needed for proper training.

\subsection{About participant observation}

The first general observation was that, during the first class, all students embraced the HEM and tried to carry out the activities it proposed. However, from the second class onwards, attitudes were varied: some students kept working as in the first class, while others also used the traditional printed material.

When solving problems, the students that worked with the HEM presented a more exploratory attitude than those working with the printed material and pen and paper. Working with the GeoGebra applets included in the HEM allowed the students to explore different solutions. The activities proposed were enriched, since the digital environment allowed students to use multiple strategies and apply different pieces of prior knowledge, as shown by the records of classroom discussions. It should also be noted that students were able to autonomously select those GeoGebra tools that they deemed appropriate to solve the problem. They worked on a trial-and-error basis, making mistakes and then correcting them, as some of the constructions handed in show, where there are objects that were initially used and then hidden after deciding that they were not useful to solve the problem.

\subsection{About the analysis of student work at exams}

To find evidence of differences in relation to acquired knowledge, written student production at their second mid-term was analyzed, comparing how students who used the HEM solved the problems with how those who were in the control group did. Only the activities related to the topic taught using the HEM were considered.

No significant differences were found between both groups. This means that there is no evidence that the HEM had an impact on exam performance specifically, even if it did have one on other aspects, as discussed in previous sections.

\section{CONCLUSIONS}

It can be concluded that, for the most part, the HEM achieved the proposed didactic goals: students were able to adopt a computer tool to work with mathematical problems with autonomy for solving and self-correcting their work, they were able to more easily understand three-dimensional mathematical objects through 3D-visualization features, they became acquainted with GeoGebra applets, and they could discuss multiple strategies, as opposed to what happens when they use just pen and paper. 
However, there were several factors that affected the experience negatively (number of computers available, time, attitudinal aspects), which ultimately resulted in students not being able to exploit the HEM to its fullest potential. This work yielded some light on the barriers faced when integrating this type of material, including student preconceptions such as considering that the analytical aspect is more important than the graphical one, or considering that the only thing that matters is training for exams. On the other hand, some positive contributions of the HEM surfaced in relation to changes in the role of the students - they were more open to trying different solutions and to search for strategies to solve mathematical problems. The HEM also offered possibilities for using different registers of representation, which is considered to be valuable in the Specific Didactics of Mathematics. In the future, improvement variables and the barriers faced will be addressed, while exploring the use of mobile devices, given the high availability of this type of device among students.

\section{REFERENCES}

Aragón, V. (2010). La observación en el ámbito educativo. Innovación y Experiencias Educativas, 35, 1-10

Argos, J., \& Ezquerra, P. (2013). Entornos hipertextuales y educación. TESI, 14(3), 175-190.

Ariza, C. A., \& Andrada, O. A. (2008). El hipertexto educativo: una herramienta para la mejora de la calidad del proceso de enseñanza-aprendizaje a distancia. In Congreso Virtual Iberoamericano de Calidad En Educación a Distancia.

Ascheri, E., Pizarro, R., Astudillo, G., García, P., \& Culla, M. E. (2014). Software educativo en línea para la enseñanza y el aprendizaje de temas de Cálculo Numérico. Revista Digital Matemática, Educación e Internet, 14(2). doi:10.18845/rdmei.v14i2.1662

Aveleyra, E., Dadamia, D., \& Racero, D. (2014). Una propuesta de aprendizaje universitario con TIC para recursantes. Revista Iberoamericana de Educación En Tecnología y Tecnología En Educación, 13, 36-42.

Barrena, E., Falcón, R. M., Ramírez, R., \& Ríos, R. (2011). Presentación y resolución dinámica de problemas mediante GeoGebra. Union. Revista Iberoamericana de Educación Matemática, 25, 161-174.

Berney, S., \& Bétrancourt, M. (2016). Does animation enhance learning? A meta-analysis. Computers and Education, 101, 150-167. doi:10.1016/j.compedu.2016.06.005

Bravin, C., \& Pievi, N. (2008). Documento metodológico orientador para la investigación educativa. Buenos Aires: Ministerio de Educación de la Nación Organización de los Estados Iberoamericanos.

Brescó, E., Verdú, N., \& Flores, O. (2012). Valoración del estudiantado sobre el uso del material interactivo en materias de la Universidad de Lleida. EDUTEC Revista Electrónica de Tecnología Educativa, 42

Brousseau, G. (1986). Fundamentos y métodos de la didáctica de la matemática. Recherches En Didactique de Mathématiques, 7(2), 33-115.

Brousseau, G. (2007). Iniciación al estudio de la teoría de las situaciones didácticas. Editorial Libros Del Zorzal.

Bucari, N., Abate, S. M., \& Melgarejo, A. (2007). Estructura didáctica e innovación en educación matemática. Revista Argentina de Enseñanza de la Ingeniería, 8, 17-28.

Claro, M., Preiss, D. D., San Martín, E., Jara, I., Hinostroza, J. E., Valenzuela, S. .. Nussbaum, M. (2012). Assessment of 21 st century ICT skills in Chile: Test design and results from high school level students. Computers and Education, 59(3), 1042-1053. doi:10.1016/j.compedu.2012.04.004

Coll, V., \& Blasco, O. (2009). Aprendizaje de la estadística económico empresarial y uso de las TICs. EDUTEC Revista Electrónica de Tecnología Educativa, 28.

Corbetta, P., \& Fraile Maldonado, M. (2007). Metodología y técnicas de investigación social ( $\left.2^{\mathrm{a}} \mathrm{ed}.\right)$. Mc Graw-Hill.

Del Río, L., Búcari, N., \& González, A. (2014). La integración de las TIC en las clases de matemática en el nivel universitario: ¿cómo afrontar este desafío? In Congreso Iberoamericano de Ciencia, Tecnología, Innovación y Educación. Buenos Aires.

Del Río, L., Búcari, N., \& Sanz, C. (2015). Material didáctico hipermedia para la Enseñanza de la Matemática en carreras de ingeniería: Inicios de una investigación. In XIX Enseñanza de las matemáticas en carreras de ingeniería. San Nicolás de los Arroyos.

Del Río, L., Búcari, N., \& Sanz, C. (2016). Uso de recursos hipermediales para la enseñanza y el aprendizaje de la matemática. In II Congreso Internacional de Enseñanza de las ciencias y la Matemática. Tandil.
Del Río, L., Sanz, C., \& Búccari, N. (2017). Actitudes de los estudiantes frente a un material hipermedial para el aprendizaje de la matemática: un estudio de caso. Revista Iberoamericana de Educación en Tecnología y Tecnología en Educación, 17, 24-33.

Di Domenicantonio, R. M., Costa, V. A., \& Vacchino, M. C. (2011). La visualización como mediadora en el proceso de enseñanza y aprendizaje del Cálculo Integral. Union. Revista Iberoamericana de Educación Matemática, 27, 75-87.

Dolecek, G. J. (2012). MATLAB-Based Program for Teaching Autocorrelation Function and Noise Concepts. IEEE Transactions on Education, 55(3), 349356. doi:10.1109/TE.2011.2176736

Duval, R. (1998). Registros de representación semiótica y funcionamiento cognitivo del pensamiento. In F. Hitt (Ed.), Investigaciones en Matemática Educativa II (pp. 173-201). México: Grupo Editorial Iberoamérica.

Duval, R. (2006). Un tema crucial en la educación matemática: La habilidad para cambiar el registro de representación semiótica. La Gaceta de La RSME, 9(1), 143-168

Gonzalez, J., Medina, P., Vilanova, S., \& Astiz, M. (2011). Un aporte para trabajar sucesiones numéricas con Geogebra. Revista de Educación Matemática.

Guerra, A. A., Mora, D. A., Nieves, L. A. P., Pimentel, G. J. M., \& León, C. C. (2016). Software educativo para el trabajo con matrices. Revista Digital: Matemática, Educación e Internet, 16(2), 1-12.

Hernández, R., Fernández, C., \& Baptista, M. del P. (2010). Metodología de la investigación ( $5^{\mathrm{a}}$ ed.). México DF: Mc Graw-Hill.

Humanante-Ramos, P. R., García-Peñalvo, F. J., \& Conde-González, M. Á. (2017) Electronic devices and web 2.0 tools: usage trends in engineering students. International Journal of Engineering Education (IJEE), 33(2B), 790-796.

Hurtado, L. (2011). Validación de una escala de actitudes hacia las matemáticas. Investigación Educativa, 15(28), 99-108.

Insunza, S., Alonso, D., \& Alvarez, A. (2009). Desarrollo de software para el aprendizaje y razonamiento probabilístico: El casode SIMULAPROB. Union. Revista Iberoamericana de Educación Matemática, 18, 135-149.

Kitchenham, B., Pearl, O., Budgen, D., Turner, M., Bailey, J., \& Linkman, S. (2009). Systematic literature reviews in software engineering - A systematic literature review. Information and Software Technology, 51(1), 7-15. doi:10.1016/j.infsof.2008.09.009

Martín-Gutiérrez, J., Luís, J., Contero, M., Alcañiz, M., Pérez-López, D. C., \& Ortega, M. (2010). Design and validation of an augmented book for spatial abilities development in engineering students. Computers and Graphics (Pergamon), 34(1), 77-91. doi:10.1016/j.cag.2009.11.003

Martorelli, S. Martorelli, S., \& Sanz, C. (2014). Evaluación del material educativo Histologi@. Diseño del Plan de Evaluación y primeros resultados de su implementación. In IX Congreso de Tecnología en Educación \& Educación en Tecnología.

Mayer, R. (2003). The promise of multimedia learning: using the same instructional design methods across different media. Learning and Instruction, 13, 125139. doi:10.1016/S0959-4752(02)00016-6

Mendezabal, M. \& Tindowen, D. (2018). Improving students' attitude, conceptual understanding and procedural skills in differential calculus through microsoft mathematics. Journal of Technology and Science Education, 8(4), 385397. doi:10.3926/jotse. 356

Mohamad, M., Hussin, H., \& Shahizan, S. (2015). Adult learners' perceptions of designed hypermedia in a blended learning course at a public University in Malaysia. TOJET The Turkish Online Journal of Educational Technology, 14(1), 31-38

Molinero, L. M. (2001). Comparación de un resultado de tipo ordinal entre dos muestras independientes. Sociedad Española de Hipertensión - Liga Española para la lucha contra la hipertensión arterial. Retrieved from http://www. seh-lelha.org/stat1.htm

Moos, D. C. (2014). Setting the stage for the metacognition during hypermedia learning: What motivation constructs matter? Computers and Education, 70 , 128-137. doi:10.1016/j.compedu.2013.08.014

Morales, M., Herrera, S., Fennema, C., \& Goñi, J. (2014). Estrategias de m-learning para la enseñanza de la Matemática en Carreras de Ingeniería. In II Congreso Argentino de Ingeniería. Mar del Plata.

Müller, N., \& Seufert, T. (2018) Effects of self-regulation prompts in hypermedia learning on learning performance and self-efficacy. Learning and Instruction, 58, 1-11. doi:10.1016/j.learninstruc.2018.04.011

Nóbile, C. I., \& Sanz, C. V. (2014). Procesos de integración de tecnologías de la información y la comunicación en instituciones de educación superior. El caso de la Facultad de Ciencias Económicas de la Universidad Nacional de la Plata. Facultad de Informática. La Plata: Universidad Nacional de La Plata.

Oliveiro, C. L. (2013). Plataforma de Ensino Siena: refletindo sobre a utilização das TIC no processo de ensino e aprendizagem. Union. Revista Iberoamericana de Educación Matemática, 35, 9-18.

Pantoja, R., López, A., Ortega, M. I., \& Hernández, J. C. (2014). Diseño instruccional para el aprendizaje del concepto de límite: Un estudio de caso en el ITCG, 
la UJED, la UASLP y la UAN . Union. Revista Iberoamericana de Educación Matemática, 37, 91-110.

Pirro, A. L., Fernández, M. E., Daher, N., Quercia, M. C., Barbano, R., \& Moro, L. (2012). La simulación y visualización de curvas paramétricas. Una mirada pedagógica en el diseño de material multimedial. In Congreso Argentino de Enseñanza de La Ingeniería.

Pompeya, V. E. (2008) "Blended Learning". La importancia de la utilización de diferentes medios en el proceso educativo (Tesis de Magíster). Facultad de Informática, Universidad Nacional de La Plata, La Plata.

Rabeh, M. (2018). Interactive Hypermedia Programs and its Impact on the Achievement of University Students Academically Defaulting in Computer Sciences. International Journal of Advanced Computer Science and Applications, 9(3), 142-147.

Ramírez, R. (2014). Un Ambiente Virtual de Aprendizaje para la Enseñanza del Cálculo en Educación Superior. In IX Conferencia Latinoamericana de Objetos y Tecnologías del Aprendizaje (LACLO) (pp. 728-732).

Sanz C., \& Zangara, A. (2013). Encuesta generada por la Dirección de Educación a Distancia de la Facultad de Informática de la UNLP.

Schivo, M. E., Sgreccia, N., \& Caligaris, M. (2009). Recursos didácticos en análisis matemático I: Su vinculación con la visualización dinámica y el interés en el aprendizaje de los futuros ingenieros. Elcaso de la FRSN-UTN. In I Congreso Internacional de Enseñanza de Las Ciencias y La Matemática. Tandil.

Siegel, S. (1970). Estadística no paramétrica aplicada a las ciencias de la conducta. México: Editorial Trillas.

Sorando, J. M. (2012). Blog de aula: la clase sigue en casa. Union. Revista Iberoamericana de Educación Matemática, 31, 139-151.

Sun, Z., Xie, K.\& Anderman, L. (2018) The role of self-regulated learning in students' success in flipped undergraduate math courses. The Internet and Higher Education, 36, 41-53. doi:10.1016/j.iheduc.2017.09.003

Yingprayoon, J. (2015). Teaching Mathematics using Augmented Reality. In 20th Asian Technology Conference in Mathematics (pp. 384-391).

How to cite this article: del Río, L. S., Sanz, C. V., \& Búcari, N. D. (2019). Incidence of a hypermedia educational material on the Teaching and Learning of Mathematics. Journal of New Approaches in Educational Research, 8(1), 50-57. doi:10.7821/naer.2019.1.334 